\title{
Commentary
}

\section{The 2009 H1N1 Pandemic Adds to Our Knowledge of Influenza Pathogenesis}

\author{
David H. Walker \\ From the Department of Pathology, University of Texas Medical \\ Branch, Galveston, Texas
}

The article by Shieh et al ${ }^{1}$ on the pathology and pathogenesis of the 2009 pandemic H1N1 influenza A virus is a landmark work in the long evolution of our understanding of this ever-threatening public health challenge. During the intervals between the pandemics of 1889, 1918, 1957,1968 , and 2009, most of the public, including physicians, did not distinguish between colds and the flu. Influenza A virus is not well controlled in the overall population by antiviral drugs and vaccination, and even during these interpandemic periods, the toll from seasonal influenza in the United States was a remarkable 36,000 deaths annually. Therefore, pathologists have much to potentially contribute to the better understanding the pathogenesis of influenza.

This study of 100 fatal cases of 2009 pandemic H1N1 influenza $A$ is a remarkably large sample of cases that were etiologically well documented and were investigated with state-of-the-art contemporary methods. Immunohistochemical $(\mathrm{IHC})$ analyses revealed that the distribution of the target cells of the 2009 cases differed from those of seasonal influenza and H5N1 avian influenza. ${ }^{2,3}$ The 2009 H1N1 influenza virus infected not only the tracheobronchial epithelium but also the submucosal glands and alveolar lining cells, particularly type II pneumocytes, which were distinguished from alveolar macrophages and type I pneumocytes by antisurfactant IHC, as sloughed alveolar cells are not easily identified by morphology alone and could be mistaken on a purely morphological basis as alveolar macrophages. ${ }^{1}$ The concordance of influenza viral antigen with diffuse alveolar damage and infection of type II pneumocytes is critical to understanding the pathogenesis of the 2009 pandemic disease. IHC and polymerase chain reaction were also used to definitively identify the agents of superinfecting bacterial pneumonia: Streptococcus pneumoniae, S. pyogenes, Hemophilus influenzae, Staphylococcus aureus, and even methicillin-resistant strains.

This series of 100 cases adds significantly to the information in two other particularly excellent 2009 H1N1 in- fluenza autopsy series. A series of 34 cases largely from the New York City medical examiner's office provided correlations with computerized tomographic pulmonary lesions but in contrast had a higher rate of secondary bronchopneumonia (55\% versus 29\%), less infection of alveolar type I and II pneumocytes, and less apparent colocalization of diffuse alveolar damage and viral antigen. ${ }^{4}$ A Brazilian study of 21 pandemic H1N1 influenza autopsies described the same pathology (DAD, interstitial pneumonia, airway ${ }^{5}$ lesions, with extensive hemorrhage and/or microthrombi in some patients). ${ }^{5} \mathrm{IHC}$ was used in this study to address aspects of immunity and immunopathogenesis, including identifying many CD8 T cells, granzyme B expressing cells, and expression of Toll-like receptor 3 (TLR3) and gamma interferon by macrophages and alveolar epithelium in these patients. Intriguing data from experimental mouse infections suggest that TLR3, the receptor for double-stranded RNA, the genetic material of influenza A virus not only plays a role in controlling viral infection but also contributes to pathogenic innate and adaptive responses that vary with the viral load. ${ }^{6}$

Although fatal outcomes of influenza $A$ are present as outliers in pandemics or in seasonal disease, H5N1 avian influenza cases provide an exception. Indeed, the current pandemic has been relatively mild. Thus, it is not surprising that the autopsy series has contained a high proportion of patients with comorbid conditions. Mechanisms governing the enhanced disease severity in obesity, asthma, and pregnancy remain as unanswered questions that will provide future directions of research. Interestingly, a study of diet-induced obese mice immune to seasonal H3N2 influenza and challenged with 2009 pandemic $\mathrm{H} 1 \mathrm{~N} 1$ virus revealed more severe illness, higher mortality and viral titers, and reduced levels in the lung of gamma interferon, virus-specific CD8 T cells, and memory CD8 $\mathrm{T}$ cell gamma interferon production than nonobese mice. ${ }^{7}$ It would be useful to pursue these leads in studies of humans with influenza.

Accepted for publication April 21, 2010.

Address reprint requests to David H. Walker, M.D., University of Texas Medical Branch, 301 University Boulevard, Galveston, TX 77555-0609. E-mail: dwalker@utmb.edu. 
Other future avenues of research should pursue unanswered questions such as the mechanism of cell death, the pathogenic role of the immune response, the potential importance and pathogenesis of alveolar capillary thrombi, the variable occurrence and pathogenesis of myocarditis, myopathy, and acute encephalopathy, which have apparently not been features of the current pandemic, and the mechanisms of hematogenous dissemination, which seems to have been rare in humans during pandemics of the past century.

An extensive picture of human pathology is critical, but often animal models are required to provide insights into human disease. The molecular basis of the attachment of influenza A virus by its receptor, hemagglutinin, to the sialic acid-containing host cell receptor is critical to understanding why the anatomical distribution of lesions of an experimental animal and humans do or do not coincide. The precise determination of the target cells in this study by Shieh et al provides the reality from which sialy-terminating oligosaccharide moieties can be investigated ${ }^{8,9}$ and whether the predictions of studies in experimental animals such as ferrets can be relied on. ${ }^{10-12}$

Our knowledge of influenza in 2010 has left many stones unturned. The Centers for Disease Control Pathology Branch ${ }^{1}$ has used the material in their hands yet again to contribute to knowledge of pathogenesis as well as pathology as they have done many times previously, such as with hantavirus pulmonary syndrome, the 2001 anthrax attacks, and coronavirus severe acute respiratory syndrome. Yet other gaps in knowledge could be closed if pathologists were organized to do a greater number of well-organized autopsy studies. Appropriately collected tissues could address questions ranging from molecular mechanisms to the pathological basis for radiological images. Even this straightforward anatomical problem would require harvesting the exact tissues of the lesions that had been imaged close to the time of death.

What the dead have taught the living about influenza is clearly told in history. In 1889, Leichtenstern was convinced from clinical and anatomical evidence that a primary pneumonia was produced by the poison of influenza. As a result of careful bacteriological studies of autopsies in 1919 in which he isolated Hemophilus influenzae, from 23 of 28 cases, Wolbach was tempted to believe that the early deaths with abundant hyaline membranes and later bacterial pneumonia "simply represent different stages of the same process." ${ }^{13}$ However, he considered that failure to reproduce influenza in human studies involving inoculation with pure cultures of $H$. influenzae ${ }^{14}$ was "strong argument against it being the cause of influenza." After the isolation of influenza A virus from swine by Robert Shope in 1930 and from humans by Andrewes, Laidlaw, and Smith in 1933, ${ }^{15}$ Hers and Mulder were prepared in 1957 to identify by immunofluorescence staining that tracheobronchial ciliated epithelial cells and alveolar lining cells are the infected targets. ${ }^{16}$

Influenza A virus circulates not only by human-to-human transmission with seasonal oscillation between the Northern and Southern Hemispheres but also resides in wild aquatic fowl. There are 16 hemagglutinin and nine neuraminidase types that may emerge by accidental spillover into swine or other routes and threaten to establish transmission to and among humans. The threat will not disappear, and we will face a more serious pandemic in the future. Thus, it is of paramount importance to learn as much about the present pandemic as possible to sufficiently meet the challenge of these future pandemics.

\section{References}

1. Shieh WJ, Blau DM, Denison AM, DeLeon-Carnes M, Adem P, Bhatnagar J, Sumner J, Liu L, Patel M, Batten B, Greer P, Jones T, Smith C, Bartlett J, Montague J, White E, Rollin D, Gao R, Seales C, Jost H, Metcalfe M, Goldsmith CS, Humphrey C, Schmitz A, Drew C, Paddock C, Uyeki TM, Zaki SR: 2009 pandemic Influenza A (H1N1): Pathology and pathogenesis of 100 fatal cases in the U.S. Am J Pathol 2010, 166-175

2. Guarner J, Paddock CD, Shieh WJ, Packard MM, Patel M, Montague JL, Uyeki TM, Bhat N, Balish A, Lindstrom S, Klimov A, Zaki SR: Histopathologic and immunohistochemical features of fatal influenza virus infection in children during the 2003-2004 season. Clin Infect Dis 2006, 43:132-140

3. Taubenberger JK, Morens DM: The pathology of influenza virus infections. Annu Rev Pathol Mech Dis 2008, 3:499-522

4. Gill JR, Sheng ZM, Ely SF, Guinee Jr DG, Beasley MB, Suh J, Deshpande C, Mollura DJ, Morens DM, Bray M, Travis WD, Taubenberger JK: Pulmonary pathologic findings of fatal 2009 pandemic influenza A/H1N1 viral infections. Arch Pathol Lab Med 2010, 134:235-243

5. Mauad T, Hajjar LA, Callegari GD, da Silva LFF, Schout D, Galas FRBG, Alves VAF, Malheiros DMAC, Auler Jr JOC, Ferreira AF, Borsato MRL, Bezerra SM, Gutierrez PS, Caldini ETEG, Pasqualucci CA, Dolhnikoff M, Saldiva PHN: Lung pathology in fatal novel human influenza A (H1N1) infection. Am J Respir Crit Care Med 2010, 181:72-79

6. Le Goffic R, Balloy V, Lagranderie M, Alexopoulou L, Escriou N Flavell R, Chignard M, Si-Tahar M: Detrimental contribution of the toll-like receptor (TLR)3 to influenza A virus-induced acute pneumonia. PloS Pathog 2006, 2:0526-0535

7. Karlsson EA, Sheridan PA, Beck MA: Diet-induced obesity impairs the T cell memory response to influenza virus infection. J Immunol 2010 184:3127-3133

8. Childs RA, Palma AS, Wharton S, Matrosovich T, Liu Y, Chai W, Campanero-Rhodes MA, Zhang $Y$, Eickmann M, Kiso M, Hay A, Matrosovich M, Feizi T: Receptor-binding specificity of pandemic influenza $A(H 1 N 1) 2009$ virus determined by carbohydrate microarray. Nature Biotechnol 2009, 27:797-799

9. van Riel D, Munster VJ, de Wit E, Rimmelzwaan GF, Fouchier RAM Osterhaus ADME, Kuiken T: Human and avian influenza viruses target different cells in the lower respiratory tract of humans and other mammals. Am J Pathol 2007, 171:1215-1223

10. Maines TR, Jayaraman A, Belser JA, Wadford DA, Pappas C, Zeng H, Gustin KM, Pearce MB, Viswanathan K, Shriver ZH, Raman R, Cox NJ, Sasisekharan R, Katz JM, Tumpey TM: Transmission and pathogenesis of swine-origin $2009 \mathrm{~A}(\mathrm{H} 1 \mathrm{N1} 1)$ influenza viruses in ferrets and mice. Science 2009, 325:484-487

11. Munster VJ, de Wit E, van demn Brand JMA, Herfst S, Schrauwen EJA, Bestebroer TM, van de Vijver D, Boucher CA, Koopmans M, Rimmelzwaan GF, Kuiken T, Osterhaus ADME, Fouchier RAM: Pathogenesis and transmission of swine-origin 2009 A (H1N1) influenza virus in ferrets. Science 2009, 325:481-483

12. Rowe T, León AJ, Crevar CJ, Carter DM, Xu L, Ran L, Fang Y, Cameron CM, Cameron MJ, Banner D, Ng DCK, Ran R, Weirback HK, Wiley CA, Kelvin DJ Ross TM: Modeling host responses in ferrets during A/California/07/2009 influenza infection. Virology 2010, 401:257-265

13. Wolbach SB: Comments on the pathology and bacteriology of fatal influenza cases, as observed at Camp Devens, Mass. Bull Johns Hopkins Hosp 1919, 338:104-109

14. Anonymous author: Some interesting though unsuccessful attempts to transmit influenza experimentally. Public Health Reports 1919 , 34:33-67

15. Zimmer SM, Burke DS: Historical perspective - emergence of influenza A (H1N1) viruses. N Engl J Med 2009, 361:279-285

16. Hers JF, Mulder J: Broad aspects of the pathology and pathogenesis of human influenza. Am Rev Respir Dis 1961, 83:84-89 